\title{
Brussels not to be the fulcrum
}

Brussels

A MEEIING; in Bonn last week put the finishing touches to the charter for Eureka, the French-inspired plan to stimulate European collaboration in advanced technology. The charter is the basis on which European foreign and research ministers will formally launch Eureka at a meeting at Hannover on 5 and 6 November.

What emerges from the charter is a flexible administrative structure under which it would be up to European companies to work out among themselves projects on which they might collaborate and then to seek government approval. Companies will usually have to foot whatever bills arise from their own resources.

Under the charter, participating governments (which could include governments not members of the European Community) will appoint a "high representative" as the focus for plans drawn up by national companies and also a means of liaison with opposite numbers elsewhere. There will be regular meetings of research ministers from participating countries, with a rotating chairmanship.

The role foreseen for the European Commission is not the dominant one for which some in Brussels had been hoping. The Commission will participate in Eureka as if it were a government, but the

charter forsees scope for "supportive measures" that the Commission may be able to provide.

At next month's meeting in Hannover, representatives will be asked to consider a number of specific projects for European collaboration, including the development of a 64-megabit memory chip, microprocessors with operating cycle times measured in picoseconds and high-power industrial lasers.

Meanwhile, it seems that the West German government is backing away from its earlier offer to make extra funds available for Eureka projects. The finance minister, Gerhard Stoltenberg, has now made it plain that any such funds would have to come from the 1986 research budget (DM7,500 million for next year). But there are reports that West German research minister Heinz Riesenhuber has not yet abandoned hope of raising DM1,000 million to support Eureka during 1987-88.

Elsewhere, France has committed FF1,000 million for Eureka but it is not clear how much of the money is new, or simply relabelled. The German view is close to the British government, which is insisting that Eureka projects should be supported either by the companies involved or by the usual sources of venture capital.

Anna Lubinska

\section{Eureka}

\section{Avoiding the Esprit pitfalls}

\section{Paris}

THE French view of European Commission participation in their pet project Eureka, originally inspired by the challenge of the US Strategic Defense Initiative (SDI or "star wars"), is that the Commission should enter only as another nation state, and not as an overall controlling body. And now the French view seems to have prevailed (see above).

Last week senior advisers of the French research minister, Hubert Curien, explained their motives. "We had to avoid the sirens of Esprit", the European research programme in information technology established by Belgian Commissioner Etienne Davignon 2-3 years ago, they said. It seems the French have bad memories of the early days of Esprit. The Commission apparently proposed a bureaucracy of some hundreds of officials to run it, and both Britain and France baulked at the prospect. After a struggle, the two countries established a "light" management structure, under which Esprit has had some "positive" results.

It is just because of this success that the risk was great that Eureka would be drawn inexorably into the Brussels net, where it would not flourish. Eureka will have to have $\grave{a}$ la carte project financing, partners outside the European Community, and is designed to produce commercially competitive projects, none of which is easy under the Treaty of Rome. Eureka must also be close to and highly responsive to industry. Esprit had shown some of these qualities, but it involved only precompetitive research. However successful Esprit had been (for the latest assessment see page 661), the commercial qualities needed of Eureka put it in another class.

As for the structure now proposed, in which nations will be able to play their own cards more vigorously than within the European Council of Ministers, this would not exaggerate national tensions and divergences they say in Paris. Rather each state brings its own views - leading to "extraordinarily rich" debate. Even the British view that Eureka must be marketled, in contrast to the French technologypull approach, is a welcome contribution.

But France is not intending to "shortcircuit" the Community, Curien's advisers insisted. Eureka needs a structure that derives from industry and is not imposed from above. This is an action in the Community's interests, Paris officials say.

\section{$\underset{\text { Paris }}{\text { A germ of an idea }}$}

"Artificial seEDs" are at the top of the French proposals in biotechnology for the Eureka high-technology collaboration programme, due to be discussed at ministerial level in Hannover on 5-6 November. According to Yves Demarly, the Orsay plant scientist who will lead the programme if it gains European support, the idea is to coat minute somatic plant embryos - embryos derived from cell cultures rather than seeds - with some protective substance so that they could be distributed just like seeds themselves.

The advantage is that it would be possible to distribute clones of precise genetic content, as opposed to the relatively random genes of seeds, and to prepare hybrids that could not be obtained classically by sexual recombination.

The embryos would have to be stabilized (at present they would last only a few days) and the coats would have to be designed to dissolve or otherwise disintegrate in the field. The coats could contain a food supply, systems to protect the embryo against pathogens in the soil (such as antagonistic bacteria or fungi), and "starter substances" - plant hormones such as auxins and cytokinins.

"We can already coat somatic embryos of lucerne [a legume] in a kind of jelly, and get 100 per cent germination", Demarly

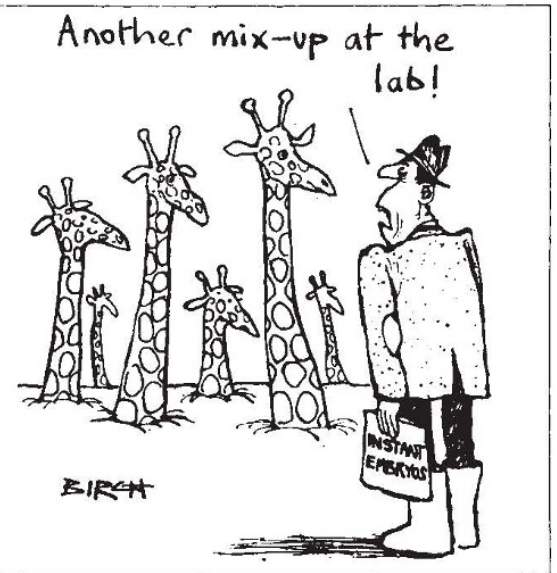

says, but there is a long way to go before the concept could be made practical. But patents are already being taken out on artificial coatings in the United States, and France is beginning to see the danger to its seed companies, which have an extraordinary 10 per cent of the $\mathfrak{£ 2 0 , 0 0 0}$ million world seed market. Eureka's role would be to establish and support a European development programme in the area.

Already 30 companies have shown an interest in the project, including France's largest chemicals company RhônePoulenc, the principal French seed company Limagrain and the Swiss pharmaceuticals giant Ciba-Geigy. With so many interested parties, it will be difficult to settle on a definite proposal in time for Hannover. Robert Walgate 